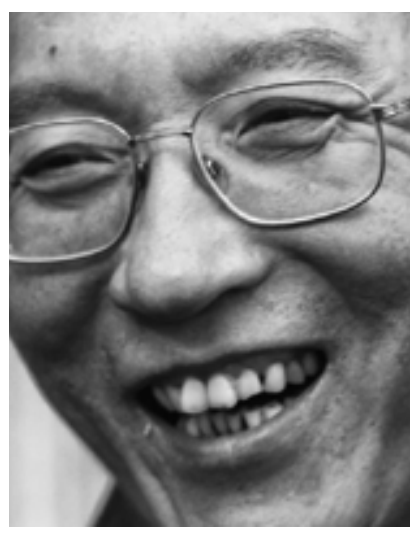

Nobel Peace Prize winner Liu Xiaobo died on 13 July 2017. aged 61. PC: Handout
To add insult to injury, Liu Xiaobo was incinerated the day after he died, and his wife was forced to proceed to a 'sea burial', dispersing his ashes in the sea near Dalian so that there would be no grave where his supporters could gather to mourn him.

\section{Remembering Liu Xiaobo One Year On}

Jean Philippe Béja

When he learned that Liu Xiaobo had won the Nobel Peace Prize, Vaclav Havel-who had not been acknowledged by the Nobel Academy-was extremely happy. Although his doctor had strictly forbidden him to drink alcohol, he opened a bottle he kept hidden for the great occasions, and drank to his success. When asked to write a foreword for the collection of Liu's works that I edited, he did it enthusiastically. In 2011, the Czech dissident who had spent many years in prison before being rewarded with the presidency of the Czechoslovak Republic, died in Prague, aged 75.

Liu Xiaobo was not so lucky: on 13 July 2017, more than eight years after his arrest, he died of liver cancer in a Shenyang hospital, surrounded by plainclothes policemen who had not allowed him one minute of intimacy with his wife Liu Xia. He was not the first Nobel Peace Prize laureate to die in prison. Before him, in 1936, Carl Von Ossetski, a pacifist who had been jailed by Hitler, died in a prison hospital in Berlin. Germany was then in the hands of the Nazis.

To add insult to injury, Liu Xiaobo was incinerated the day after he died, and his wife was forced to proceed to a 'sea burial', dispersing his ashes in the sea near Dalian so that there would be no grave where his supporters could gather to mourn him.

Liu's wife, a poet and artist who had never been involved in politics, spent eight and a half years under house arrest. Her crime? To have been Liu Xiaobo's wife, and to have refused to clearly break with him (huaqing jiexian). During all these years, she was isolated from the world, followed by plainclothes policemen wherever she went, and only allowed to be driven 400 miles to the Jinzhou jail to see her husband for half an hour every month. 52 years after Yu Luoke denounced the 'blood theory' (xuetong lun) that stipulated that political positions are transmitted through family association, 40 years after the famous Third Plenum of the Eleventh Central Committee launched the policy of reform and opening up, a woman was deprived of her freedom only because she was related to a man that the Party had deemed 'an enemy of the State'! 
After Xiaobo died, she could not collect the letters he had written her during his imprisonment, and could not see his medical reports to understand when he was diagnosed with cancer. Everything had disappeared, the authorities said, in a convenient fire that engulfed the Jinzhou jail just two weeks before his death. In July of this year, thanks to the pressure exerted on the Chinese government by German Chancellor Angela Merkel, she was allowed to leave China and has since settled in Berlin.

I rushed to see her, but although she is now safe in Germany, she refuses to give interviews or to have her declarations published. Her freedom will not be complete as long as her younger brother Liu Hui is under parole and can be sent back to jail at the whim of the Party leaders. But she reminded me: 'I don't understand politics, anyway, and I am not interested.'

When they met in the early 1980s, Liu Xiaobo, like her, did not understand politics. A student at Jilin Normal University, he did not take part in the Democracy Wall Movement (minzhu qiang), but worked in a group of poets in his native province. A staunch individualist, a Nietzschean, he made a name for himself as a 'black horse' (heima) on the Chinese literary scene with an article entitled 'Crisis: The Literature of the New Epoch Faces a Crisis' (Liu 1986). In this article, he denounced liberal intellectuals' self-satisfaction, their tendency to consider themselves the only victims of Maoist terror, and to assume the posture of the counsellor to the Prince. He exhorted them to cut the umbilical chord with the Party-state and 'think for themselves'. His words deeply shocked liberal and conservative writers alike. A born provocateur, he declared in 1988 that if it took 100 years of British presence for Hong Kong to become what it now was, China should be colonised for 300 years to reach that degree of modernity (Jin 1988).

This iconoclasm makes Liu Xiaobo a direct heir to the May Fourth intellectuals who did not hesitate to vehemently denounce Chinese traditional culture. A successful intellectual, he was invited to the most famous Western Universities-the dream of all Chinese intellectuals at that time-as he was widely different from his fellow writers.

But when confronted with history, Liu Xiaobo changed. He was in New York as a visiting scholar at Columbia when the 1989 pro-democracy movement shook his motherland. He immediately decided to go back and went straight to Tiananmen, where he stayed until the massacre. He did not refrain from criticising the students' behaviour, saying that they were not acting democratically. He also criticised them 
I feel that those who perished that day are looking down on me from above ... I do my best to make every word form my pen a cry from the heart for the souls of the dead.

Liu Xiaobo

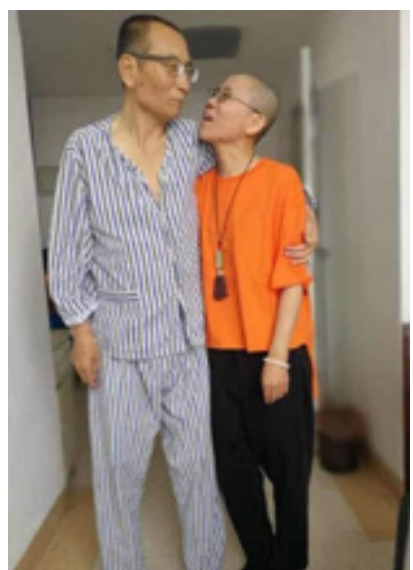

Liu Xiaobo and his wife Liu Xia. PC: Supplied for asking the government to reverse the verdict it had passed on their movement by declaring it a 'counter-revolutionary turmoil': 'Why do our fellow citizens feel so grateful towards reversal of verdicts? To send a righteous person to hell is an exorbitant privilege, to reverse the verdict is so too' (Liu 1989, 277).

The students did not blame him for his attitude, and on the night of 3 June he helped convince them to leave the Square. After the massacre, he took refuge in the home of an Australian diplomat, but after a few days, he could not stand to be safe while his students and friends were being pursued by the police. He was arrested and sent to Qincheng prison for a year. During his imprisonment, he declared in a televised interview on CCTV that nobody had died on the Square on that night. Although it was true, he later deeply regretted granting this interview to the Party's official mouthpiece.

This decided the fate of Liu Xiaobo. In his words: 'June 1989 has been the major turning point in my life which is just over one half of a century in length' (Liu 2012a, 321); 'I feel that those who perished that day are looking down on me from above ... I do my best to make every word from my pen a cry from the heart for the souls of the dead' (Liu 2012b, 293). The elitist Nietszchean turned into a caring activist and philosopher. 'When the famous members of the elite refuse, at the most dangerous moment, to rise in order to defend their ethics and their conscience, when they refuse to pay the individual price, the masses do not have the duty to support them' (Liu 2002, 8).

During the 1990s, Liu worked hand in hand with Ding Ziling and the Tiananmen Mothers in order to obtain the truth about the massacre. June Fourth led him to appreciate the courage of ordinary citizens who gave their lives to protect the students. The years he was free were spent launching petitions to protest the Party's repression, to denounce the oppression of marginalised citizens, writing on the children exploited in brick factories, on the fate of migrant workers (nongmingong), and enjoining his fellow citizens to dare speak truth to power. 'Dictatorships need lies and violence in order to maintain the coercion and fear upon which they depend ... No single person, of whatever status, can fight back against regime violence alone, but the refusal to participate in lying is something that every person can accomplish. To refuse to lie in day-to-day public life is the most powerful tool for breaking down a tyranny built on mendacity' (Liu 2012b, 295). 


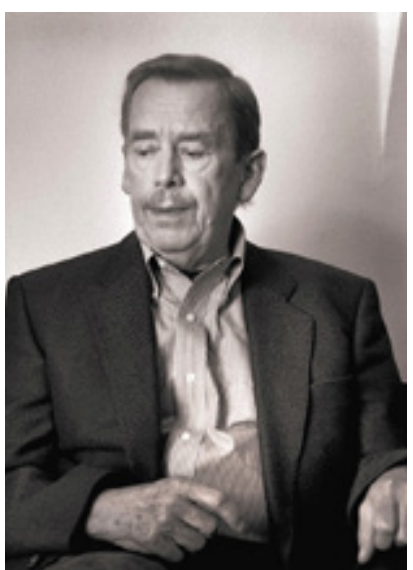

Vaclav Havel (1936-2011).

PC: Jiri Jiroutek
Like Vaclav Havel, Liu Xiaobo exhorted his compatriots to live in truth. His penetrating analyses of the regime, his conviction that the peaceful growth of an independent civil society was the best way to fight the tyranny of the Party, and his deep engagement with non-violence made him one of the most remarkable Chinese intellectuals of the twenty-first century. After his release from three years in a re-education-throughlabour camp in 1999, he became one of the most respected personalities in the dissident sphere. He enjoyed the esteem both of old Party cadres disgusted by the 4 June massacre, such as Mao's former secretary Li Rui; of intellectuals active in the 1980s, such as historian Bao Zunxin with whom he developed a profound friendship; and of the younger generation, such as Liu Di and Yu Jie who became active after 1989. In such a fragmented milieu, this is a very remarkable achievement, which probably explains why Liu received such a heavy sentence in 2009.

Although the Party has consistently tried to erase his imagehis essays and articles were never published in China after 1989-he still enjoys a strong support in dissident circles, and his all-out engagement with non-violence will definitely influence the future behavior of the opposition. His commitment to the cause of democracy, his emphasis on the necessity to uphold the memory of the June Fourth Massacre, his unceasing protest against human rights violations will continue to inspire the activists who dare rise against the reign of strong men. Liu's call to his fellow citizens to use truth to undermine a system built on lies makes his legacy more important than ever in an increasingly repressive China. 